\title{
Awareness and Attitude of Public towards Dental Procedures and Safety Protocols in COVID-19 Scenario: A Cross-sectional Study
}

\author{
Prakash Nidawani ${ }^{1}$, Girish P Galagali ${ }^{2}$, Vishnupriya B Seethapathy ${ }^{3}$, Arun K Acharya ${ }^{4}$, Santosh K Bung ${ }^{5}$
}

\begin{abstract}
Aim: To assess the awareness and attitude of public toward dental procedures and safety protocols in COVID-19 scenario in India Materials and methods: A cross-sectional survey was conducted among people from various regions of India in questionnaire format. It comprised 22-variable, structured, close-ended questions, and the respondents were divided based on their age, sex, educational qualification, and region. Data were analyzed using SPSS software version 20.0.

Results: In total, 1064 people participated from various regions of India. Most of the participants were postgraduates, and male-to-female ratio was almost equal. The major proportion of age group who responded was below 45 years. Almost $88.6 \%$ of the participants were aware that dentists are at higher risks and $87.6 \%$ of the people expect their dentists to wear personal protective equipment (PPE) during treatment procedures. $81.8 \%$ of the people preferred cashless transaction as a modality of payment option in dental office. $66.8 \%$ of the people irrespective of their education level opted newspaper and print media as their major source of information for updating themselves and $83.3 \%$ of the participants opted online or telephonic appointment prior to visiting their dentists.

Conclusion: We dentists being the healthcare professionals are at higher risks to various infectious diseases. So we should not panic and should continue our services toward the public health. We should also ensure that our practice is up-to-date to manage this pandemic crisis.

Clinical significance: To give an insight into dental practitioners about prevailing awareness and understanding of public and their response in accepting dental care in this COVID pandemic scenario.

Keywords: Attitude, Coronavirus, COVID-19, Cross-sectional study, Dental practice, Knowledge, Pandemic, Questionnaire-based study. Journal of Oral Health and Community Dentistry (2020): 10.5005/jp-journals-10062-0083
\end{abstract}

\section{INTRODUCTION}

The novel coronavirus, COVID-19, is the serious threat to the society's overall health and prosperity and has nearly recorded 937,391 deaths globally and 83,198 deaths in India (WHO Coronavirus Disease (COVID-19) Dashboard September 17, 2020) up-to-date. This viral infection is believed to be originated from the biggest seafood and live animal market present in Wuhan city of Hubei Province in Central China with a population over 11 million. It has been declared as Pandemic by WHO in the month of January 2020.

It is caused by Severe Acute Respiratory Syndrome Coronavirus 2 (SARS-CoV-2), a new emergent first recognized in Wuhan wet market in December 2019. Genetic sequencing of the virus suggests that it is a betacoronavirus closely linked to the Severe Acute Respiratory Syndrome Coronavirus (SARS-CoV-1) and Middle East Respiratory Syndrome-related Coronavirus (MERS-CoV), which resulted in higher mortality rates.

The COVID-19 is identified in saliva of infected patients, and it shows that saliva can play a vital role in human-to-human transmission that remains the main mode of spread. ${ }^{1}$ This is through (1) respiratory droplets released via coughing or sneezing; (2) aerosol, typically during aerosol generating clinical procedures; and (3) mucosal membrane contact with fomites. ${ }^{2,3}$ Feco-oral transmission has been speculated, ${ }^{4}$ given the detection of viral RNA in stools, reported gastrointestinal (GI) symptoms, and Angiotensin-converting Enzyme II (ACE2) expression along the
1-3,5 Department of Prosthodontics, Crown and Bridge Including Implantology, Navodaya Dental College, Raichur, Karnataka, India

${ }^{4}$ Department of Public Health Dentistry, Navodaya Dental College, Raichur, Karnataka, India

Corresponding Author: Girish P Galagali, Department of Prosthodontics, Crown and Bridge Including Implantology, Navodaya Dental College, Raichur, Karnataka, India, Phone: +91 9845215288, e-mail: drgirish232@ gmail.com

How to cite this article: Nidawani P, Galagali GP, Seethapathy VB, et al. Awareness and Attitude of Public towards Dental Procedures and Safety Protocols in COVID-19 Scenario: A Cross-sectional Study. J Oral Health Comm Dent 2020;14(3):97-103.

Source of support: Nil

Conflict of interest: None

Gl-tract. ${ }^{5}$ Now evidence of in utero or transplacental transmission has been reported. ${ }^{6}$

Symptoms of COVID-19 include fever, cough, and acute respiratory disease, with severe cases leading to multiorgan failure and comorbid factors leading to death. Clinical and virological studies that have collected repeated biological samples from confirmed patients demonstrate that shedding of SARS-CoV-2 is highest in upper respiratory tract (URT) early in the course of the disease, within the first 3 days from onset of symptoms.

(c) The Author(s). 2020 Open Access This article is distributed under the terms of the Creative Commons Attribution 4.0 International License (https:// creativecommons.org/licenses/by-nc/4.0/), which permits unrestricted use, distribution, and non-commercial reproduction in any medium, provided you give appropriate credit to the original author(s) and the source, provide a link to the Creative Commons license, and indicate if changes were made. The Creative Commons Public Domain Dedication waiver (http://creativecommons.org/publicdomain/zero/1.0/) applies to the data made available in this article, unless otherwise stated. 
The incubation period is on an average of about 5 to 6 days, but can be up to 14 days. During this period, also known as "presymptomatic period," some infected persons can be contagious from 1 to 3 days before symptom onset. It is important to recognize that presymptomatic transmission still requires the virus to be spread via infectious droplets or by direct/indirect contact with body fluids from an infected person. An asymptomatic case is a person with SARS-CoV-2 who does not develop any symptoms. ${ }^{7}$

Among the healthcare professions, dental professionals are particularly at higher risk due to the possibility of aerosols produced by saliva droplets that can be inhaled. When it comes in contact with skin and mucous membrane or when it gets dislodged on the surface of dental office or on any other materials that is used during dental procedures, it will cause contamination. Aerosols that becomes the main source of transmission of microorganisms are differentiated based on particle size as spatter $(>50 \mu \mathrm{m})$, droplets $(\leq 50 \mu \mathrm{m})$, and droplet nuclei $(\leq 10 \mu \mathrm{m}){ }^{9-11}$ In dental settings, $90 \%$ of the aerosols produced are extremely small $(<5 \mu \mathrm{m}) .{ }^{11}$ Spatter, being large particle, will fall until it contacts other objects. Example: floor, countertop, sink, bracket, table, computer, patient, or operator., ${ }^{9,12}$

Droplets remain suspended in the air until they evaporate, leaving droplet nuclei that contain microorganisms related to respiratory infections. ${ }^{7,8}$ Droplet nuclei can contaminate surfaces in a range of $3 \mathrm{ft}$ and may remain airborne for 30 minutes to 2 hours. ${ }^{7,10,11}$ Furthermore, the susceptibility of developing this COVID-19 infection is influenced by virulence, viral load (dose), and pathogenicity of microorganisms, along with the host's immune response.

To manage the threat of the continuing SARS-CoV-2 infection and risk to public health caused by COVID-19, oral health professionals need themselves to be updated about the latest information and guidelines in dental practice. On the contrary, it is the duty of every person seeking dental treatment to follow certain safety measures and protocols to prevent the exposure and spread of infection during dental treatment procedures.

This present study was undertaken to assess the awareness and attitude of public toward dental procedures and safety protocols during this pandemic spread of SARS-CoV-2.

\section{Materials and Methodology}

The present cross-sectional survey was done on 1064 people from various regions of India to assess the information mainly regarding the knowledge and attitude of public toward dental procedures and safety protocols that are expected to be followed during this life-threatening situation. The information was collected during the period of lockdown from 15 May to 15 June (sample size of 1000 was calculated to avoid sampling errors). Expecting a high response rate, this questionnaire was sent to 1200 people out of whom 1064 people responded.

The questionnaire was created using Google forms and sent to people via various social media platforms all over India. People voluntarily willing to participate in the study are included in the study, whereas those who refused to participate or who could not understand or answer the questionnaire were excluded from the study.

A 22-variable, structured, close-ended questionnaire in English language was created and circulated among the participants through various social media platforms. A 3-point Likert scale is used for recording the response. These responses were kept confidential and anonymous to encourage honest responses.
The data were entered into SPSS v20.0 software, percentage was calculated, and Chi-squared test was applied. The level of significance was kept at $p<0.05$.

\section{Results}

A cross-sectional survey was done to assess the knowledge and attitude of general public and dentistry in COVID-19 scenario.

Of which, 50.5\% (536) were male and 49.5\% (526) were females, majority of the participants were postgraduates (51.5\%), followed by professional degree (31.5\%), high school certified (10.9\%), and primary school certified (6.4\%) (Table 1). The major proportion of age group who responded to the survey was below 45 years.

Showing the awareness, among $66.8 \%$ were using newspaper/ television as their main source of information regarding COVID-19 and Aarogya Setu application (7.0\%) being the least. Regarding the incubation period, around $86.4 \%$ were aware of it. Almost $88.6 \%$ of the participants have the opinion that dentists are at higher risks and $87.6 \%$ of the participants expect their dentists to wear PPE during treatment procedures. Response of people regarding the quality of masks stated that 38\% opted N95 masks, whereas 27\% opted surgical masks. 55.1\% were aware that cost of dental treatment may rise after COVID-19 outbreak and so $81.8 \%$ of the people preferred cashless transaction for payment in dental office (Table 2).

Table 3 depicts gender-wise representation of response to the study. Females were more aware and more protective when compared to male population and even most of the females had opted for cashless payment mode.

Table 4 depicts the association of awareness and attitude with respect to education. It is found that irrespective of their education levels, people are still using newspaper or television as their trusted device for updating themselves. And people from each group stated that they were aware that dental procedures are capable of spreading COVID-19 infection via aerosols of infected person and above $60 \%$ of the people wanted their dentist to wear PPE during dental treatment.

Table 1: Sociodemographic data

\begin{tabular}{lcc}
\hline Characteristics & Number & Percentage \\
\hline Age & & \\
$\quad$ Below 45 years & 780 & 73.4 \\
45-65 years & 218 & 20.5 \\
$\quad$ Above 65 years & 64 & 6.0 \\
Sex & & \\
$\quad$ Female & 526 & 49.5 \\
$\quad$ Male & 536 & 50.5 \\
Educational qualification & & \\
Professional degree & 335 & 31.5 \\
$\quad$ Graduate/postgraduate & 543 & 51.1 \\
High school certified & 116 & 10.9 \\
Primary school certified & 68 & 6.4 \\
Region & & \\
$\quad$ North & 123 & 11.6 \\
South & 609 & 57.3 \\
Central & 61 & 5.7 \\
East & 119 & 11.2 \\
West & 150 & 14.1 \\
\hline
\end{tabular}


Table 2: General awareness and attitude

\begin{tabular}{|c|c|c|}
\hline & Numbe & Perce \\
\hline \multicolumn{3}{|c|}{ Aware of coronavirus before Wuhan outbreak } \\
\hline No & 785 & 73.9 \\
\hline Yes & 277 & 26.1 \\
\hline \multicolumn{3}{|c|}{ Aware that COVID-19 may be asymptomatic? } \\
\hline May be & 149 & 14.0 \\
\hline No & 204 & 19.2 \\
\hline Yes & 709 & 66.8 \\
\hline \multicolumn{3}{|c|}{ Source of information on COVID-19 } \\
\hline Aarogya Setu application & 74 & 7.0 \\
\hline Friends/neighbors/doctors & 126 & 11.9 \\
\hline Newspaper/television & 709 & 66.8 \\
\hline WHO Website & 153 & 14.4 \\
\hline
\end{tabular}

Incubation period (period the virus stays in human body) of COVID-19

$\begin{array}{lrr}14 \text { days } & 918 & 86.4 \\ 21 \text { days } & 92 & 8.7 \\ 7 \text { days } & 52 & 4.9\end{array}$

Seek dental treatment if you are affected by common cold $\begin{array}{lll}\text { May be } & 147 & 13.8\end{array}$ $\begin{array}{lll}\text { No } & 786 & 74.0\end{array}$

$\begin{array}{lll}\text { Yes } & 129 & 12.1\end{array}$

Aware that dental procedures are capable of spreading COVID infection

$\begin{array}{lrr}\text { May be } & 92 & 8.7 \\ \text { No } & 139 & 13.1 \\ \text { Yes } & 831 & 78.2\end{array}$

Seek dental treatment other than emergency procedures during this pandemic

$\begin{array}{lll}\text { May be } & 119 & 11.2 \\ \text { No } & 766 & 72.1 \\ \text { Yes } & 177 & 16.7\end{array}$

Aware that you are supposed to wear mouth mask while meeting your dentist

$\begin{array}{lrr}\text { May be } & 19 & 1.8 \\ \text { No } & 37 & 3.5 \\ \text { Yes } & 1006 & 94.7\end{array}$

Aware that dentists are at high risk in treating COVID-19positive patients

$\begin{array}{lrr}\text { May be } & 50 & 4.7 \\ \text { No } & 71 & 6.7 \\ \text { Yes } & 941 & 88.6\end{array}$

Aware that you are supposed to wash/sanitize your hands before entering the dental operatory

$\begin{array}{lrr}\text { May be } & 21 & 2.0 \\ \text { No } & 36 & 3.4 \\ \text { Yes } & 1005 & 94.6\end{array}$

Type of mask you think is affordable to wear during dental office visit

\begin{tabular}{lll} 
Cloth mask & 255 & 24.0 \\
N95 & 404 & 38.0 \\
N95 respirator & 116 & 10.9 \\
Surgical mask & 287 & 27.0 \\
\hline
\end{tabular}

Contd...
Contd...

Number Percentage

Take prior appointments online/telephonic before you visit your dentist

$\begin{array}{lcr}\text { May be } & 61 & 5.7 \\ \text { No } & 116 & 10.9 \\ \text { Yes } & 885 & 83.3 \\ \text { Seek phone or online consultation from your dentist } & \\ \text { May be } & 132 & 12.4 \\ \text { No } & 190 & 17.9 \\ \text { Yes } & 740 & 69.7\end{array}$

Inform your dentist about your travel and medical history before starting any procedures

$\begin{array}{lrr}\text { May be } & 48 & 4.5 \\ \text { No } & 44 & 4.1 \\ \text { Yes } & 970 & 91.3\end{array}$

Expect your dentist should use PPE during dental treatment

$\begin{array}{lrr}\text { I don't know } & 90 & 8.5 \\ \text { No } & 42 & 4.0 \\ \text { Yes } & 930 & 87.6\end{array}$

Aware that the cost of dental treatment may rise after COVID-19 outbreak

$\begin{array}{lll}\text { May be } & 304 & 28.6 \\ \text { No } & 173 & 16.3 \\ \text { Yes } & 585 & 55.1\end{array}$

Follow the appointment scheduled by your dentist

$\begin{array}{lll}\text { May be } & 66 & 6.2\end{array}$

$\begin{array}{lrr}\text { No } & 83 & 7.8\end{array}$

$\begin{array}{lll}\text { Yes } & 913 \quad 86.0\end{array}$

Aware that only emergency dental procedures will be performed until this pandemic is successfully dealt with

May be $\quad 81 \quad 7.6$

$\begin{array}{lll}\text { No } & 115 & 10.8\end{array}$

$\begin{array}{lll}\text { Yes } & 866 \quad 81.5\end{array}$

Prefer cashless payment

$\begin{array}{lrr}\text { May be } & 109 & 10.3 \\ \text { No } & 92 & 8.7 \\ \text { Yes } & 861 & 81.1\end{array}$

Aware that any ulcer or fluid-filled swelling in your mouth can be related to manifestations of COVID-19

$\begin{array}{lll}\text { May be } & 252 & 23.7 \\ \text { No } & 496 & 46.7 \\ \text { Yes } & 314 & 29.6\end{array}$

Think that dentists play a main role in educating the public and increasing awareness about the pandemic COVID-19

$\begin{array}{lrr}\text { May be } & 188 & 17.7 \\ \text { No } & 95 & 8.9 \\ \text { Yes } & 779 & 73.4\end{array}$

Follow the instructions and safety protocols prescribed by your dentist

May be $\quad 24 \quad 2.3$

No $\quad 22 \quad 2.1$

Yes $1016 \quad 95.7$ 
Table 3: Gender-wise representation of response

\begin{tabular}{lcccccc}
\hline \multicolumn{6}{c}{ Sex } \\
\hline Female & Male & $\chi^{2}$ value & $p$-value & Remarks \\
\hline Aware of coronavirus before Wuhan outbreak \\
No & 383 & 402 & 0.66 & 0.42 & $\begin{array}{l}\text { Not } \\
\text { significant }\end{array}$ \\
Yes & 143 & 134 & & &
\end{tabular}

Aware that COVID-19 may be asymptomatic?

$\begin{array}{lrrrrr}\text { May be } & 67 & 82 & 12.1 & 0.002 & \text { Significant } \\ \text { No } & 82 & 122 & & & \\ \text { Yes } & 377 & 332 & & & \end{array}$

Source of information on COVID-19

\begin{tabular}{|c|c|c|c|c|c|}
\hline $\begin{array}{l}\text { Aarogya Setu } \\
\text { application }\end{array}$ & 29 & 45 & 14.5 & 0.002 & Significant \\
\hline $\begin{array}{l}\text { Friends/neighbors/ } \\
\text { doctors }\end{array}$ & 46 & 80 & & & \\
\hline Newspaper/television & 373 & 336 & & & \\
\hline WHO Website & 78 & 75 & & & \\
\hline \multicolumn{6}{|c|}{$\begin{array}{l}\text { Incubation period (period the virus stays in human body) of } \\
\text { COVID-19 }\end{array}$} \\
\hline 14 days & 448 & 470 & 2.64 & 0.27 & $\begin{array}{l}\text { Not } \\
\text { significant }\end{array}$ \\
\hline 21 days & 53 & 39 & & & \\
\hline 7 days & 25 & 27 & & & \\
\hline
\end{tabular}

Seek dental treatment if you are affected by common cold

$\begin{array}{lrrrrr}\text { May be } & 68 & 79 & 11.8 & 0.003 & \text { Significant } \\ \text { No } & 411 & 375 & & & \\ \text { Yes } & 47 & 82 & & & \end{array}$

Aware that dental procedures are capable of spreading COVID infection

$\begin{array}{lrrrrr}\text { May be } & 45 & 47 & 6.5 & 0.04 & \text { Significant } \\ \text { No } & 55 & 84 & & & \\ \text { Yes } & 426 & 405 & & & \end{array}$

Seek dental treatment other than emergency procedures during this pandemic

$\begin{array}{lrrrrr}\text { May be } & 48 & 71 & 9.03 & 0.01 & \text { Significant } \\ \text { No } & 401 & 365 & & & \\ \text { Yes } & 77 & 100 & & & \end{array}$

Aware that you are supposed to wear mouth mask while meeting your dentist

$\begin{array}{llllll}\text { May be } & 7 & 12 & 4.5 & 0.1 & \begin{array}{l}\text { Not } \\ \text { significant }\end{array}\end{array}$

$\begin{array}{lrr}\text { No } & 13 & 24 \\ \text { Yes } & 506 & 500\end{array}$

Aware that dentists are at high risk in treating COVID-19positive patients

\begin{tabular}{lrrrrl} 
May be & 26 & 24 & 5.1 & 0.08 & $\begin{array}{l}\text { Not } \\
\text { significant }\end{array}$ \\
No & 26 & 45 & & & \\
Yes & 474 & 467 & & & \\
Aware that you are supposed to wash/sanitize your hands \\
before entering the dental operatory \\
May be \\
$\begin{array}{l}\text { No } \\
\text { No }\end{array}$ & 10 & 26 & & & \\
Yes & 505 & 500 & & & \\
\hline
\end{tabular}

Contd...
Contd...

\begin{tabular}{|c|c|c|c|c|c|}
\hline \multicolumn{6}{|c|}{ Sex } \\
\hline & Female & Male & $\chi^{2}$ value & $p$-value & Remarks \\
\hline \multicolumn{6}{|c|}{$\begin{array}{l}\text { Type of mask you think is affordable to wear during dental } \\
\text { office visit }\end{array}$} \\
\hline Cloth mask & 126 & 129 & 6.68 & 0.08 & $\begin{array}{l}\text { Not } \\
\text { significant }\end{array}$ \\
\hline N95 & 182 & 222 & & & \\
\hline N95 respirator & 64 & 52 & & & \\
\hline Surgical mask & 154 & 133 & & & \\
\hline \multicolumn{6}{|c|}{$\begin{array}{l}\text { Take prior appointments online/telephonic before you visit } \\
\text { your dentist }\end{array}$} \\
\hline May be & 27 & 34 & 13.11 & 0.001 & Significant \\
\hline No & 40 & 76 & & & \\
\hline Yes & 459 & 426 & & & \\
\hline
\end{tabular}

Seek phone or online consultation from your dentist

$\begin{array}{lrrrrr}\text { May be } & 61 & 71 & 9.24 & 0.01 & \text { Significant } \\ \text { No } & 77 & 113 & & & \\ \text { Yes } & 388 & 352 & & & \end{array}$

Inform your dentist about your travel and medical history before starting any procedures

$\begin{array}{llllll}\text { May be } & 26 & 22 & 3.52 & 0.17 & \begin{array}{l}\text { Not } \\ \text { significant }\end{array}\end{array}$

$\begin{array}{lrr}\text { No } & 16 & 28 \\ \text { Yes } & 484 & 486\end{array}$

Expect your dentist should use PPE during dental treatment

$\begin{array}{llllll}\text { I don't know } & 46 & 44 & 11.58 & 0.003 & \text { Significant }\end{array}$

No $\quad 10 \quad 32$

Yes $\quad 470 \quad 460$

Aware that the cost of dental treatment may rise after COVID-19 outbreak

$\begin{array}{llllll}\text { May be } & 143 & 161 & 1.64 & 0.44 & \begin{array}{l}\text { Not } \\ \text { significant }\end{array}\end{array}$

$\begin{array}{lrr}\text { No } & 83 & 90 \\ \text { Yes } & 300 & 285\end{array}$

Follow the appointment scheduled by your dentist

$\begin{array}{llllll}\text { May be } & 24 & 42 & 9.96 & 0.007 & \text { Significant }\end{array}$

No $\quad 32 \quad 51$

Yes $\quad 470 \quad 443$

Aware that only emergency dental procedures will be performed until this pandemic is successfully dealt with

$\begin{array}{lrrrrr}\text { May be } & 43 & 38 & 10.06 & 0.007 & \text { Significant } \\ \text { No } & 41 & 74 & & & \\ \text { Yes } & 442 & 424 & & & \end{array}$

Prefer cashless payment

$\begin{array}{llllll}\text { May be } & 59 & 50 & 1.03 & 0.59 & \text { Not }\end{array}$

$\begin{array}{lrr}\text { No } & 45 & 47 \\ \text { Yes } & 422 & 439\end{array}$

Aware that any ulcer or fluid-filled swelling in your mouth can be related to manifestations of COVID-19

$\begin{array}{llllll}\text { May be } & 112 & 139 & 16.01 & 0.0003 & \text { Significant }\end{array}$

No $\quad 278 \quad 218$

Yes $\quad 135 \quad 179$

Contd... 
Contd...

Sex

Female Male $\chi^{2}$ value $p$-value Remarks

\begin{tabular}{|c|c|c|c|c|c|}
\hline \multicolumn{6}{|c|}{$\begin{array}{l}\text { Think that dentists play a main role in educating the } \\
\text { public and increasing awareness about the pandemic } \\
\text { COVID-19 }\end{array}$} \\
\hline May be & 97 & 88 & 5.85 & 0.054 & $\begin{array}{l}\text { Not } \\
\text { significant }\end{array}$ \\
\hline No & 36 & 59 & & & \\
\hline Yes & 392 & 387 & & & \\
\hline \multicolumn{6}{|c|}{$\begin{array}{l}\text { Follow the instructions and safety protocols prescribed by your } \\
\text { dentist }\end{array}$} \\
\hline May be & 12 & 12 & 6.45 & 0.04 & Significant \\
\hline No & 5 & 17 & & & \\
\hline Yes & 509 & 507 & & & \\
\hline
\end{tabular}

\section{Discussion}

Novel coronavirus that has been detected in December 2019 has grown into global pandemic. Indian Government had imposed Janata curfew, lockdown, and several other methods to restrict public movement and break the chain. Since India has announced unlocking of economic activity, as the dental offices started providing service, there is a need to analyze the public awareness, attitude, and their preparedness toward receiving dental treatment. In this scenario of reopening of the dental offices, the present survey helps the Indian dental professionals with people's feedback, so that they will know the prevailing level of public awareness and their mind-set toward dental office visits. To obtain COVID-related information, $66.8 \%$ of the participants were using television, newspaper, and other print media, which clearly states that media still plays a major role in providing current information. Media should provide not only high TRP-rated and sensational news but

Table 4: Awareness and attitude with respect to education

Educational qualification

Graduate/postgraduate High school certified Primaryschoolcertified Professionaldegree $\chi^{2}$ value $p$-value

\section{Aware of coronavirus before Wuhan outbreak}

$\begin{array}{lrrrrr}\text { No } & 395 & 101 & 67 & 222 & 42.3 \\ \text { Yes } & 148 & 15 & 1 & 113\end{array}$

Aware that COVID-19 may be asymptomatic?

$\begin{array}{ll}\text { May be } & 80 \\ \text { No } & 61 \\ \text { Yes } & 402\end{array}$

80

$17 \quad 7$

$32 \quad 53$

61

Yes
Source of information on COVID-19

Aarogya Setu application 39

Friends/neighbors/doctors $\quad 45$

Newspaper/television $\quad 377$

WHO Website

82
$8 \quad 6$

$15-20$

$77-40$

16

Incubation period (period the virus stays in human body) of COVID-19

\begin{tabular}{|c|c|c|}
\hline 14 days & 472 & 99 \\
\hline 21 days & 56 & 7 \\
\hline 7 days & 15 & 10 \\
\hline
\end{tabular}

Seek dental treatment if you are affected by common cold

$\begin{array}{lrrr}\text { May be } & 88 & 17 & 47 \\ \text { No } & 402 & 82 & 17 \\ \text { Yes } & 53 & 17 & \end{array}$

Aware that dental procedures are capable of spreading COVID infection

$\begin{array}{lrrrrr}\text { May be } & 49 & 18 & 4 & 21 & 20.53 \\ \text { No } & 72 & 23 & 11 & 33 & \\ \text { Yes } & 422 & 75 & 53 & 281 & \end{array}$

Seek dental treatment other than emergency procedures during this pandemic

$\begin{array}{lrrrrr}\text { May be } & 69 & 17 & 8 & 25 & 17.3 \\ \text { No } & 392 & 82 & 55 & 237 & \\ \text { Yes } & 82 & 17 & 5 & 73 & \end{array}$

Aware that you are supposed to wear mouth mask while meeting your dentist

\begin{tabular}{lrrrrr} 
May be & 7 & 4 & 3 & 5 & 0.32 \\
No & 17 & 6 & 3 & 11 & \\
Yes & 519 & 106 & 62 & 319 & \\
\hline
\end{tabular}


Contd...

Educational qualification

Graduate/postgraduate Highschool certified Primaryschoolcertified Professional degree $\chi^{2}$ value p-value

Aware that dentists are at high risk in treating COVID-19-positive patients

$\begin{array}{lrrrrr}\text { May be } & 19 & 17 & 6 & 8 & 44.23<0.0001 \\ \text { No } & 31 & 14 & 7 & 19 & 308\end{array}$

Aware that you are supposed to wash/sanitize your hands before entering the dental operatory

$\begin{array}{lrrrrr}\text { May be } & 10 & 2 & 2 & 7 & 5.6 \\ \text { No } & 16 & 1 & 4 & 15 & \\ \text { Yes } & 517 & 113 & 62 & 313\end{array}$

Type of mask you think is affordable to wear during dental office visit

$\begin{array}{lrrrr}\text { Cloth mask } & 128 & 32 & 11 & 84 \\ \text { N95 } & 200 & 40 & 38 & 126 \\ \text { N95 respirator } & 63 & 7 & 5 & 41 \\ \text { Surgical mask } & 152 & 37 & 14 & 84\end{array}$

Take prior appointments online/telephonic before you visit your dentist

May be $34 \quad 3$

$\begin{array}{lllll}\text { No } & 35 & 22 & 42 & 17\end{array}$

$\begin{array}{lllll}\text { Yes } & 474 & 91 & 24 & 296\end{array}$

Seek phone or online consultation from your dentist

$\begin{array}{lrrrr}\text { May be } & 66 & 18 & 8 & 40 \\ \text { No } & 80 & 25 & 43 & 42 \\ \text { Yes } & 397 & 73 & 17 & 253\end{array}$

Inform your dentist about your travel and medical history before starting any procedures

May be 29

No 19

$29 \quad 4$

No

19

$4 \quad 7$

10

10
14

$495 \quad 108 \quad 56$

$15.7 \quad 0.07$

Expect your dentist should use PPE during dental treatment

$\begin{array}{lrrrrr}\text { I don't know } & 30 & 27 & 21 & 12 & 98.4 \\ \text { No } & 15 & 5 & 3 & 19 & \\ \text { Yes } & 498 & 84 & 44 & 304\end{array}$

Aware that the cost of dental treatment may rise after COVID-19 outbreak

$\begin{array}{lrrrrr}\text { May be } & 124 & 53 & 48 & 79 & 96.5 \\ \text { No } & 100 & 19 & 9 & 45 & \\ \text { Yes } & 319 & 44 & 11 & 211\end{array}$

Follow the appointment scheduled by your dentist

$\begin{array}{lrrrrr}\text { May be } & 41 & 12 & 6 & 7 & 179.6 \\ \text { No } & 21 & 12 & 32 & 18 & \\ \text { Yes } & 481 & 92 & 30 & 310 & \end{array}$

Aware that only emergency dental procedures will be performed until this pandemic is successfully dealt with

\begin{tabular}{|c|c|c|c|c|c|c|}
\hline May be & 42 & 11 & 8 & 20 & 31.9 & $<0.0001$ \\
\hline No & 50 & 20 & 18 & 27 & & \\
\hline Yes & 451 & 85 & 42 & 288 & & \\
\hline \multicolumn{7}{|c|}{ Prefer cashless payment } \\
\hline May be & 42 & 25 & 16 & 26 & \multirow[t]{3}{*}{81.5} & \multirow[t]{3}{*}{$<0.0001$} \\
\hline No & 29 & 10 & 19 & 34 & & \\
\hline Yes & 472 & 81 & 33 & 275 & & \\
\hline \multicolumn{7}{|c|}{ Aware that any ulcer or fluid-filled swelling in your mouth can be related to manifestations of COVID-19 } \\
\hline May be & 105 & 44 & 38 & 64 & \multirow[t]{3}{*}{68.12} & \multirow[t]{3}{*}{$<0.0001$} \\
\hline No & 261 & 51 & 25 & 159 & & \\
\hline Yes & 176 & 21 & 5 & 112 & & \\
\hline
\end{tabular}

Contd... 
Educational qualification

\begin{tabular}{|c|c|c|c|c|c|c|}
\hline & & \multirow[b]{2}{*}{$\chi^{2}$ value } & \multirow[b]{2}{*}{ p-value } \\
\hline & Graduate/postgraduate & High school certified & Primary school certified & Professional degree & & \\
\hline \multicolumn{7}{|c|}{ Think that dentists play a main role in educating the public and increasing awareness about the pandemic COVID-19 } \\
\hline May be & 97 & 16 & 12 & 63 & 11.9 & 0.06 \\
\hline No & 57 & 5 & 1 & 32 & & \\
\hline Yes & 389 & 95 & 55 & 240 & & \\
\hline \multicolumn{7}{|c|}{ Follow the instructions and safety protocols prescribed by your dentist } \\
\hline May be & 12 & 3 & 3 & 6 & 9.74 & 0.14 \\
\hline No & 7 & 1 & 1 & 13 & & \\
\hline Yes & 524 & 112 & 64 & 316 & & \\
\hline
\end{tabular}

also valuable professional expert-related articles, with valid and truthful information to the general public. Aarogya Setu app though promoted by the Government of India, least number of participants opted for it, maybe due to fear of disclosing their personal identity and personal information. Around 3.5\% of the participants were unaware of using mouth masks, so dental professionals and office team should make all efforts in educating patients who visit the dental office and impose the measures to implement wearing of masks.

A total of $83.3 \%$ of the participants preferred online or telephonic appointment prior visiting the dentist which will avoid accumulation of people in groups, thereby ensuring the safety of the patients and over $69.7 \%$ of the people showed a positive response to teledentistry, which can be connected through appropriate applications with the clinicians and seek an appointment through phone if further treatment is required. Dentists can prescribe medications in a fixed format to treat symptomatically.

Number of cashless transactions shot up after currency note ban and remained high till March 2017 and had gradually come down. COVID-19 global pandemic has fast-tracked mobile payments (FinTech Analyst at S\&P Global Market Intelligence). $81.1 \%$ of the participants preferred cashless payment so appropriate methods to receive contactless payments should be installed in every dental office for the convenience of the patients. Digital paperwork will reduce contact between the dentist and patients. This shall make the transactions and data sharing more effective.

About $58.7 \%$ of the people with graduation and $62.9 \%$ of the people with professional qualification were aware of an increase in the treatment cost of dental procedures. In the dental office, the preventive protocols like wearing PPE by dentists and staff, protective disposable wears to patients, sanitization measures, infrastructure modifications like high vacuum extraoral suction, UV light sanitizations, office HEPA filters are adding to the cost of treatment.

\section{Conclusion}

\section{"Stop Cursing Darkness and Start Lighting a Candle"}

We dentists as a frontline healthcare professionals are at a higher risk due to the nature of treatment protocols, so we should abide by this philosophy whenever such an uncertain and challenging situation arises. In the past also, we have successfully dealt with other life-threatening infections like hepatitis, SARS, HIV, and various other fatal diseases.

We shall strive hard to elicit fear and misconception regarding this viral disease and dental practice among people. So as a professional, we stop panicking and should start our lives by taking proper preventive measures and safety protocols. Patients should be informed and educated about the expected changes in dental office protocols, cost, time, etc.

\section{References}

1. Sabino-silva R, Jardim ACG, Siqueria WL. Coronavirus COVID-19 impacts to dentistry and potential salivary diagnosis. Clin Oral Investig 2020;24(4):1619-1621. DOI: 10.1007/s00784-020-03248-x.

2. Rothan HA, Byrareddy SN. The epidemiology and pathogenesis of coronavirus disease (COVID-19) outbreak. J Autoimmun 2020;109:102433. DOI: 10.1016/j.jaut.2020.102433.

3. Doremalen NV, Gamble A, Williamson B, et al. Aerosol and surface stability of HCoV-19 (SARS-CoV-2) compared to SARS-CoV-1. N Engl J Med 2020;382(16):1564-1567. DOI: 10.1056/NEJMc2004973.

4. Yeo C, Sanghvi K, Yeo DXW. Enteric involvement of coronaviruses: is faecal-oral transmission of SARS-CoV-2 possible? Lancet Gastroenterol Hepatol 2020;5(4):335-337. DOI: 10.1016/S24681253(20)30048-0.

5. Hamming, Timens W, Bulthuis MLC, et al. Tissue distribution of ACE2 protein, the functional receptor for SARS coronavirus. A first step in understanding SARS pathogenesis. J Pathol 2004;203:631-637.

6. Sisman J, Jaleel MA, Moreno W, et al. Intrauterine transmission of SARS-CoV-2 infection in a preterm infant. Pediatr Infect Dis J 2020;39(9):265-267. DOI: 10.1097/INF.0000000000002815.

7. Weiss SR, Leibowitz JL. Coronavirus pathogenesis. Adv Virus Res 2011;81:85-164. DOI: 10.1016/B978-0-12-385885-6.00009-2.

8. Harrel SK, Molinari J. Aerosols and splatter in dentistry: a brief review of the literature and infection control implications. J Am Dent Assoc 2004;135(4):429-437. DOI: 10.14219/jada.archive.2004.0207.

9. Attkinson J, Chartier Y, Pessoa-Silva CL, et al. Natural ventilation for infection control in health-care settings. Geneva: WHO Publications/ Guidelines; 2009.

10. Sawhney A, Venugopal S, Babu GRG, et al. Aerosols how dangerous they are in clinical practice. J Clin Diagn Res 2015;9(4):52-57. DOI: 10.7860/JCDR/2015/12038.5835.

11. James R, Mani A. Dental aerosols: a silent hazard in dentistry. Int J Sci Res 2016;5(11):1761-1763.

12. Szymanska J. Dental bioaerosol as an occupational hazard in a dentist's workplace. Ann Agric Environ Med 2007;14:203-207. 